\title{
Response of Roselle (Hibiscus sabdariffa L.) to Farmyard Manure and Nitrogen-fertilizer in the semi-arid savanna of Nigeria
}

\author{
${ }^{1}$ U.M. Mera, ${ }^{2}$ B.R. Singh, ${ }^{1}$ M.D. Magaji, A. ${ }^{* 1}$ Singh, ${ }^{1}$ M. Musa \\ and ${ }^{1}$ M.J.S. Kilgori \\ ${ }^{1}$ Department of Crop Science, Usmanu Danfodiyo University, Sokoto, Nigeria. \\ ${ }^{2}$ Department of Crop Production, Abubakar Tafawa Balewa University, Bauchi, Nigeria. \\ [Corresponding author: ajitsingh66@yahoo.com]
}

\begin{abstract}
Field experiments were conducted during 1998 and 1999 rainy seasons at the Dry Land Teaching and Research Farm of Usmanu Danfodiyo University, Sokoto, to study the response of roselle to farmyard manure, nitrogen and their interaction on the growth and yield of roselle. Treatment consisted of factorial combination of four rates of farmyard manure $(0,2.5,5.0$ and 7.5 $\mathrm{t} / \mathrm{ha})$ and four levels of nitrogen fertiliser $(0,25,50$ and $75 \mathrm{~kg} \mathrm{~N} / \mathrm{ha})$ laid out in a randomized complete block design replicated three times. The result showed that there was significant response to applied manure and $\mathrm{N}$-fertiliser on number of leaves up to $5 \mathrm{t} / \mathrm{ha}$ manure and $50 \mathrm{~kg} \mathrm{~N} / \mathrm{ha}$. There was no significant increase in calyx yield by raising manure rate from 2.5-7.5 /ha or nitrogen rate from 50 to $75 \mathrm{~kg} \mathrm{~N} / \mathrm{ha}$. Thus, $2.5 \mathrm{t} / \mathrm{ha}$ manure and $50 \mathrm{~kg} \mathrm{~N} / \mathrm{ha}$ were considered adequate for calyx production in roselle in Sokoto Semi-arid Tropics. However, for maximum number of vegetable leaves additional manure (5-7.5 t/ha) and $\mathrm{N}$ fertilizer (50-75 $\mathrm{kg} \mathrm{N} / \mathrm{ha}$ ) may be necessary.

KEYWORDS: Roselle, Hibiscus sabdariffa, Farmyard manure, Nitrogen fertilizer, Semi-arid.
\end{abstract}

\section{INTRODUCTION}

Hibiscus sabdariffa is different from other species in view of its bushy branches, which are either reddish or greenish in colour, and its red or pale yellow inflated edible calyces. It is an erect and branched annual sub-shrub, (0.5-3 $\mathrm{m}$ tall) with a strong tap-root system. The flowers are borne on very short peduncles in the axils of the upper leaves, the epicalyxes are made up of 10 linear fleshy bracteoles and the calyx is 8 lobed, becoming large and fleshy after flowering (Gibbon and Pain, 1985).

It is grown extensively in the Semi-Arid savanna for local consumption and for export to the Middle East and Europe. The red acid succulent calyx are boiled with sugar to produce sorrel drink, they are also made into jellies, sauces, chutneys and preserves (Gibbon and Pain, 1985). The seeds contain about $17 \%$ oil, which is similar in properties to cottonseed oil. The seeds are boiled, fermented and dried for use as condiment for local soup preparations (Yakuwa or Batso in Hausa) before the arrival of modern substitutes (e.g maggi). The fruit contains approximately 84.5 $\%$ water, $1.7 \%$ protein, $1.0 \%$ fats and oil, and $12 \%$ carbohydrate. Its calyx contains $4 \%$ citric acid (Purseglove, 1969). Besides food, the traditional preparations from various parts of the plant such as flowers, leaves, calyx and corolla of the roselle are used as remedy for various illnesses.

The main areas of production in Nigeria are Kagara and Mokwa (Niger State), southern Jos (Plateau State), and around Ibadan (Oyo state). It is also widely grown in Kogi, Kwara, Kebbi, Sokoto, Zamfara, Katsina, Borno, Kaduna, Bauchi and Kano States (Dike, 1987; Alegbejo, 1998).

Inspite of its economic importance and the fact that the crop originated in West Africa, not much research work has been conducted on it when viewed in relation to the amount of work undertaken on its closely related species, such as cotton (Kumar et al., 1986; Dike, 1987). Relatively little has been reported on the agronomy of roselle in northern Nigeria. Now that the calyx yield is considered as important as the ribbon yield of roselle, there is a need to understand the appropriate application of farmyard manure and nitrogen fertilizer required for its maximum yield.

The soils in the Semi-arid Tropics are very low in organic matter and $\mathrm{N}, \mathrm{P}$ and $\mathrm{K}$ content and these are very necessary for growth and yield of roselle. Panchoo and Rhoden (1990) reported that the nutritional requirements of 
roselle are unknown. Tindall (1983) also reported that variety sabdariffa is adapted to a wide range of soil conditions and is often grown on relatively infertile soils, but that economic yields are obtained on soils, which are well supplied with organic matter and essential nutrients. There is therefore, the need, to determine appropriate levels of essential nutrients to be supplied through manuring for maximum production. This study was therefore undertaken to determine optimum rates of manure and $\mathrm{N}$ fertilizer for sustainable production of roselle under the semi-arid dry land conditions.

\section{MATERIALS AND METHODS}

Field experiments were conducted in 1998 and 1999 rainy seasons at the Dry Land Teaching and Research Farm of the Usmanu Danfodiyo University, Sokoto. Sokoto is located on Latitude $13^{\circ} 01^{\prime} \mathrm{N}$ and Longitude $5^{\circ} 15^{\prime} \mathrm{E}$; at an Altitude of $320 \mathrm{~m}$. It falls under semi-arid (Sudan savanna) agro-ecological zone. The total annual rainfall figures recorded near the experimental site were 705.9 and $690.4 \mathrm{~mm}$ in 1998 and 1999 cropping seasons, respectively. The rain fell between July and September with a peak in August (Figure 1). The area has extremes of temperature $\left(15-45^{\circ} \mathrm{C}\right)$, the low temperatures occurring in November-February and the high in April-May. The data on physico-chemical properties of the soils from the study area showed, that the soil was sandy in texture and slightly acidic with very low contents of organic matter and essential nutrients (Table 1).

Treatments consisted of factorial combination of four rates of manure $(0,2.5,5.0$ and 7.5 $\mathrm{t} / \mathrm{ha}$ ) and four levels of nitrogen $(0,25,50$ and $75 \mathrm{~kg} \mathrm{~N} / \mathrm{ha}$ ) laid out in a randomized complete block design, replicated three times.

Four seeds per hill were sown at an intra-row spacing of $50 \mathrm{~cm}$ inter-row spacing of $60 \mathrm{~cm}$. Four seeds per hill were sown that were later thinned to one plant per stand at the first weeding two weeks after sowing. $30 \mathrm{~kg}$ P2O5/ha as single super-phosphate was applied as basal dose at the time of plot layout. Manure rates were applied at this time while the fertilizer-N rates were split in two equal doses. The first dose was applied after the first weeding two weeks after sowing (2WAS), while the second dose was top-dressed at 6WAS. Weeding was done manually at $2 \& 6$ WAS using hand hoe.

Data was collected on number of leaves per plant and calyx yield. The data were analyzed using analysis of variance (ANOVA) and the difference between treatment means separated using the least significant differences (LSD) with the help of a micro-computer statistical package (MSTAT) (MSU, 1985).

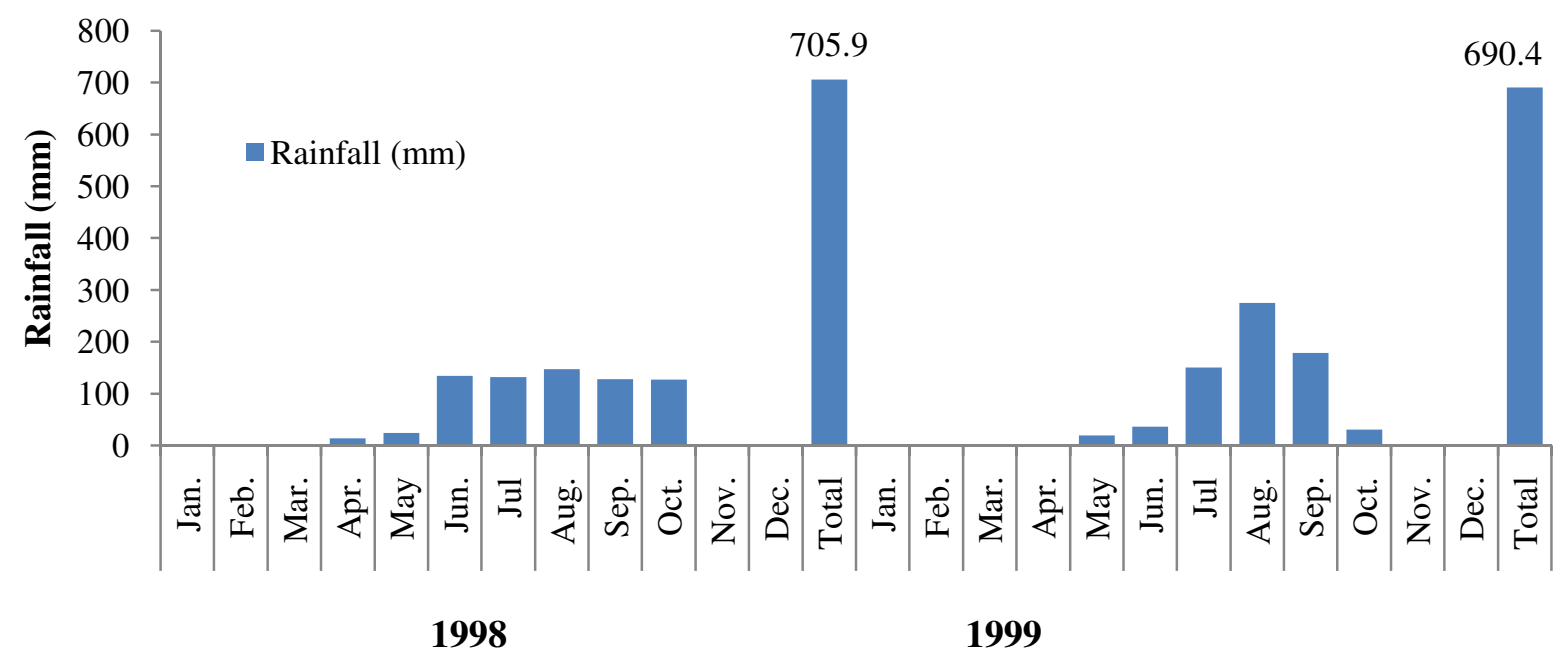

Figure 1: Monthly and total annual rainfall at the experimental site in 1998 and 1999 cropping seasons.

Table 1: Physico-chemical characteristics of the soil at the experimental site in 1998 and 1999 cropping season 


\begin{tabular}{lcc}
\hline Physico-chemical properties & 1998 Cropping Season & 1999 Cropping Season \\
\hline Physical Properties & 940 & 960 \\
Sand $(\mathrm{g} / \mathrm{kg})$ & 10 & 10 \\
Silt $(\mathrm{g} / \mathrm{kg})$ & 50 & 30 \\
Clay $(\mathrm{g} / \mathrm{kg})$ & Sandy soil & Sandy soil \\
Texture & & \\
Chemical Properties & 5.2 & 5.9 \\
$\mathrm{pH}\left(1: 1 \mathrm{H}_{2} 0\right)$ & 0.02 & 0.04 \\
Total nitrogen $(\%)$ & 0.04 & 0.08 \\
Organic C $(\%)$ & 0.002 & 0.03 \\
Available P $(\mathrm{mg} / \mathrm{g})$ & & \\
Exchangeable bases (cmol/100g) & 0.30 & 2.20 \\
Ca & 0.50 & 1.1 \\
Mg & 3.6 & 1.7 \\
K & 3.2 & 2.40 \\
Na & 8.2 & 5.8 \\
CEC (mmol/100g) & 93 & 88 \\
Base saturation $(\%)$ & & \\
\hline
\end{tabular}

\section{RESULTS AND DISCUSSION}

Number of leaves per plant

Results revealed significant $(\mathrm{P}<0.05)$ effect of manure and nitrogen on number of leaves in both seasons (Table 2). Increasing manure rate from 0 to $5 \mathrm{t} / \mathrm{ha}$ resulted in significant increase in number of leaves but further addition to $7.5 \mathrm{t} / \mathrm{ha}$ did not result in significant increase in leaf number for the two growing sessons. The least number of leaves was recorded with the control treatments in both seasons where no manure was applied. An average of 87.5 and 97.2 leaves per plant were produced by control treatment in 1998 and 1999, respectively. The positive effect of manure on the number of leaves per plant could be due to the contribution made by manure to fertility status of the soils as the soils were low in organic carbon content. Manure when decomposed increases both macro and micronutrients as well as enhances the physico-chemical properties of the soil. This could have led to high vegetative growth and hence higher number of leaves in comparison to control

Table 2: Effect of manure, nitrogen and their interaction on the number of leaves per plant.

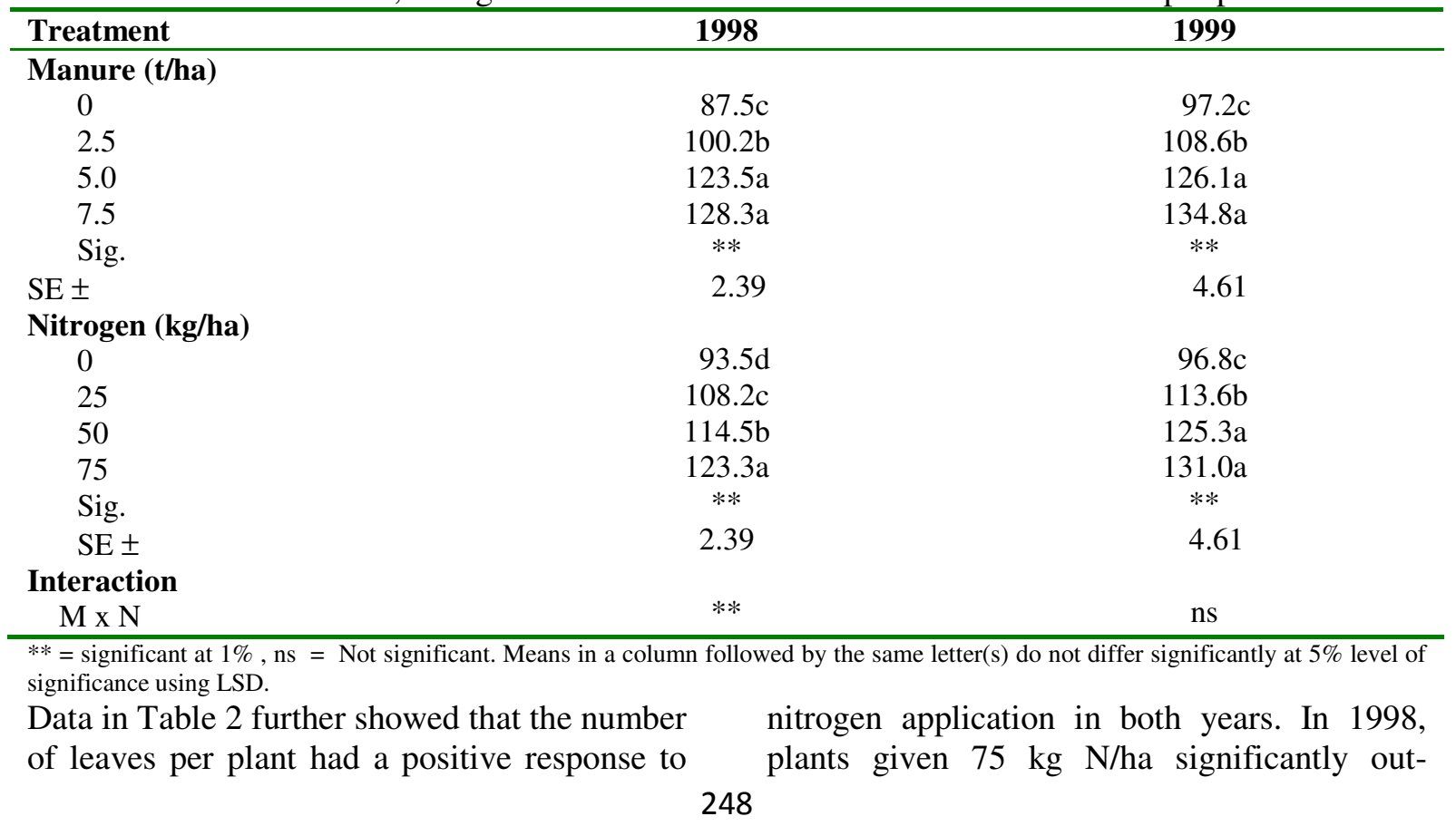


yielded the rest in leave number. It recorded an average of 123.3 leaves; which was closely followed by those given $50 \mathrm{~kg} \mathrm{~N} / \mathrm{ha}$ with average value of 114.5 leaves. Control treatment recorded the lowest number of leaves (93.5). In 1999 there was no significant $(\mathrm{P}<0.05)$ difference in leave number between plants given $50 \mathrm{~kg} \mathrm{~N} / \mathrm{ha}$ and those that received with $75 \mathrm{~kg} / \mathrm{N} / \mathrm{ha}$. It was closely followed by those given $25 \mathrm{KgN} / \mathrm{ha}$ with an average leave number of 113.6. The control treatment also had the lowwest number of leaves (96.8). The increase in leave number with nitrogen fertilizer application stressed the importance of nitrogen during the vegetative growth of crop plants (Tindall, 1992; Sarkar et al., 1997; Paschadilis et al., 1997; Okosun, 2000).

The interaction effect was significant in 1998, while it was found to be non significant in 1999 (Table 2). In 1998, the highest number of leaves was obtained from the plants treated with $7.5 \mathrm{t} / \mathrm{ha}$ manure and $75 \mathrm{~kg} \mathrm{~N} / \mathrm{ha}$; it had an average of 143 leaves per plant (Table 3).
These, however, did not differ significantly from those given either $75 \mathrm{~kg} \mathrm{~N} / \mathrm{ha}$ and $5 \mathrm{t} / \mathrm{ha}$ manure or $50 \mathrm{~kg} \mathrm{~N} / \mathrm{ha}$ and $7.5 \mathrm{t} / \mathrm{ha}$ manure. Control treatment gave the lowest number of leaves per plant (78.3) though this was not significantly different from those obtained by treating the crop with zero nitrogen and $2.5 \mathrm{t}$ manure /ha. In the absence of manure, the increasing nitrogen rate from 25 to 50 or 75 $\mathrm{kg} / \mathrm{ha}$ did not bring about significant difference in the number of leaves per plant although significantly different from the nitrogen control treatment. Similarly, in the nitrogen control treatments, treating roselle with $2.5 \mathrm{t} / \mathrm{ha}$ manure did not bring about any significant difference in leaf number from the control. There was also no significant difference in the number of leaves between treatments that received 5 and 7.5 t/ha of manure. Mugwira (1985) reported $\mathrm{N}$ application on manure to enhance its activity with resultant effect in promoting crop growth.

Table 3: Nitrogen and manure interaction effect on the number of leaves per plant during 1998 cropping season

\begin{tabular}{|c|c|c|c|c|}
\hline \multirow{2}{*}{$\begin{array}{l}\text { Nitrogen } \\
\left(\mathrm{kg} \mathrm{N} \mathrm{ha}^{-1}\right)\end{array}$} & \multirow[b]{2}{*}{0} & \multicolumn{2}{|c|}{ Manure (t/ha) } & \multirow[b]{2}{*}{7.5} \\
\hline & & 2.5 & 5.0 & \\
\hline 0 & $78.3 \mathrm{f}$ & 82.0 ef & $102.3 \mathrm{~cd}$ & $111.3 \mathrm{c}$ \\
\hline 25 & $89.7 \mathrm{e}$ & $92.7 \mathrm{de}$ & $125.7 \mathrm{~b}$ & $124.7 \mathrm{~b}$ \\
\hline 50 & $92.0 \mathrm{de}$ & $101.3 \mathrm{~cd}$ & $132.3 \mathrm{~b}$ & $134.0 \mathrm{ab}$ \\
\hline 75 & $90.0 \mathrm{e}$ & $124.7 \mathrm{~b}$ & $135.0 \mathrm{ab}$ & $143.0 \mathrm{a}$ \\
\hline $\mathrm{SE} \pm$ & \multicolumn{4}{|c|}{4.78} \\
\hline
\end{tabular}

Means followed by the same letter(s) do not differ significantly at 5\% level of significance using LSD.

\section{Calyx yield}

Dry calyx yield was significantly affected by manure rates in both the seasons (Table 4). The control treatment recorded the lowest calyx yield of 327.2 and $259.3 \mathrm{~kg} / \mathrm{ha}$ in 1998 and 1999, respectively. Varying manure rates over the control did not result in a significant difference in calyx yield in both seasons. Though the highest rate of $7.5 \mathrm{t} / \mathrm{ha}$ gave the highest yield in 1999 with an average of 388.3 $\mathrm{kg} / \mathrm{ha}$, the trend was not the same in 1998 . Where the highest yield corresponded to $5 \mathrm{t} / \mathrm{ha}$, which produced an average of $467.0 \mathrm{~kg} / \mathrm{ha}$ of dry calyx. The positive response of dry calyx yield of roselle to manure conformed to the findings of Tindall (1983) who reported that economic yield of roselle is only obtained on soils which are well supplied with organic materials and essential nutrients. Similarly, Purseglove (1969) reported that both okra and kenaf, produced best on manured soil rich in humus. The marginal difference in calyx yield due to the different rates of manure exhibited in both seasons suggests that roselle requires a moderate level of manure application.

The nitrogen effect on dry calyx yield was highly significant in 1998 and significant in 1999 season (Table 4). The highest yield was obtained when $50 \mathrm{~kg} \mathrm{~N} / \mathrm{ha}$ was applied giving an average dry calyx yield of 512.3 and 355.5 $\mathrm{kg} / \mathrm{ha}$ in 1998 and 1999, respectively. The control treatments produced the lowest dry calyx yield in both seasons (Table 4). In 1999 results indicated that there was no significant difference in dry calyx yield among 25, 50 and $75 \mathrm{~kg} \mathrm{~N} / \mathrm{ha}$. In 1998, the yield increased from $313 \mathrm{~kg} / \mathrm{ha}$ (control treatment) to as high as $512.3 \mathrm{~kg} / \mathrm{ha}$ with $50 \mathrm{~kg} / \mathrm{ha}$ nitrogen. Similarly, in 1999 the yield increased to $344.8 \mathrm{~kg} / \mathrm{ha}$ when $25 \mathrm{~kg} \mathrm{~N} / \mathrm{ha}$ given to the crop as 
compared to the control treatment (249.5 $\mathrm{kg} / \mathrm{ha}$ ). Thus, $50 \mathrm{~kg} \mathrm{~N} / \mathrm{ha}$ appeared to produce the best yield in the combined, suggesting it to be the appropriate rate for calyx production at Sokoto. Babatunde (2001) obtained the highest calyx yield of red variant roselle with $60 \mathrm{~kg}$ $\mathrm{N} / \mathrm{ha}$ at Bauchi, Nigeria. The positive response of dry calyx yield of roselle to nitrogen obtained is in conformity with the findings of many researchers. For example, Gibbon and Pain (1985) reported that roselle responded satisfactorily to moderate level of nitrogen fertilizer. Similarly Selim et al. (1993) and ElGamel et al. (1983) reported that nitrogen fertilizer increased calyx yield of roselle. Mahran et al. (1978) reported increased calyx with nitrogen application. Okosun (2000) also reported a positive response of calyx yield to nitrogen application. The increase in calyx yield of roselle as a result of nitrogen application may be attributed to an increase in photosynthetic area exhibited as a result of good vegetative growth.

Table 4: Effect of manure, nitrogen and their interaction on dry calyx yield of roselle in 1998 and 1999 cropping seasons

\begin{tabular}{llll}
\hline \multirow{2}{*}{ Treatment } & \multicolumn{3}{c}{ Dry calyx yield $\left(\mathrm{kg} \mathrm{ha}^{-1}\right)$} \\
\cline { 2 - 4 } & \multicolumn{1}{c}{1998} & \multicolumn{2}{c}{ Combined } \\
\hline Manure $(\mathrm{M})\left(\mathrm{t} \mathrm{ha}^{-1}\right)$ & $327.2 \mathrm{~b}$ & $259.3 \mathrm{~b}$ & $293.3 \mathrm{~b}$ \\
0 & $421.6 \mathrm{ab}$ & $338.8 \mathrm{a}$ & $380.2 \mathrm{a}$ \\
2.5 & $467.0 \mathrm{a}$ & $318.6 \mathrm{ab}$ & $392.8 \mathrm{a}$ \\
5.0 & $413.9 \mathrm{ab}$ & $388.3 \mathrm{a}$ & $401.1 \mathrm{a}$ \\
7.5 & $*$ & $*$ & $* *$ \\
Sig. & 48.41 & 37.57 & 32.72 \\
SE \pm & & & \\
Nitrogen $(\mathrm{N})\left(\mathrm{kg} \mathrm{ha}^{-1}\right)$ & $313.0 \mathrm{c}$ & $249.5 \mathrm{~b}$ & $281.3 \mathrm{c}$ \\
0 & $385.0 \mathrm{bc}$ & $344.8 \mathrm{a}$ & $364.9 \mathrm{~b}$ \\
25 & $512.3 \mathrm{a}$ & $355.4 \mathrm{a}$ & $387.9 \mathrm{a}$ \\
50 & $419.3 \mathrm{ab}$ & $355.3 \mathrm{a}$ & $* *$ \\
75 & $* *$ & $*$ & 32.72 \\
Sig. & 48.41 & 37.57 & \\
SE \pm & & & Ns \\
Interaction & Ns & Ns & \\
M x N & & & \\
\hline
\end{tabular}

Means in a column followed by the same letter(s) do not differ significantly at 5\% level of significance using LSD. $*=$ Significant at $5 \%, \mathrm{~ns}=$ Non significant, $* *=$ Significant at $1 \%$,

The results of the combined analysis (Table 4) indicated that differences in calyx yield due to manure were highly significant $(\mathrm{P}<0.01)$. The result showed that increasing manure rate from $2.5-7.5 \mathrm{t} / \mathrm{ha}$ did not result in significant increases in calyx yield, but the three rates differed significantly from the control. This implies that $2.5 \mathrm{t} / \mathrm{ha}$ seemed to be adequate for roselle growth at Sokoto under the prevailing circumstances of the trial. Nitrogen effect was also highly significant $(\mathrm{P}<0.01)$. Control treatment had the least yield $(281 \mathrm{~kg} / \mathrm{ha})$, while $50 \mathrm{~kg} \mathrm{~N} / \mathrm{ha}$ appeared to be the technical optimum rate for roselle production at Sokoto, because further increase in the rate to $75 \mathrm{~kg}$ $\mathrm{N} / \mathrm{ha}$ led to a decrease in yield $(387 \mathrm{~kg} / \mathrm{ha})$, though not significantly different $(434 \mathrm{~kg} / \mathrm{ha})$ from those treated roselle to nitrogen obtained is in conformity with the findings of many researchers. For example, Gibbon and Pain (1985) reported that roselle responded satisfactorily to moderate level of nitrogen fertilizer. Similarly Selim et al. (1993) and ElGamel et al. (1983) reported that nitrogen fertilizer increased calyx yield of roselle. Mahran et al. (1978) reported increased calyx with nitrogen application. Amadu and Gupta (1993) also reported similarly, with okra. Okosun (2000) also reported a positive response of calyx yield to nitrogen application. The increase in calyx yield of roselle as a result of nitrogen application may be attributed to an increase in photosynthetic area exhibited as a result of good vegetative growth.

The interaction effect was not significant in both 1998 and 1999 seasons. This non- 
significant interaction tends to signify that moderate level of fertility is required for calyx production of roselle plant.

\section{CONCLUSIONS}

From this study it may be concluded that applying $2.5 \mathrm{t} / \mathrm{ha}$ of farm-yard manure was adequate for maximum calyx production and 5-7.5 t/ha for leaves per plant. There was significant response to applied $\mathrm{N}$ on the parameters studied. $50 \mathrm{~kg} \mathrm{~N} / \mathrm{ha}$ was optimum for calyx yield and 50-75 for maximum number of leaves.

\section{REFERENCES}

Alegbejo, M.D. (1998). The potential of roselle as an industrial crop in Nigeria. A paper by Programme leader Horticultural crops Research Programme and Joint Co-ordinator NCRP (Horticulture) for Northern-western and North Eastern Nigeria. Pp. 1-6

Amadu, M.A. and Gupta, U.S. (1993). Effects of nitrogen application and sowing dates on growth and yield of okra (Abelmoscus esculentus L. Moench) varieties. J. Agric. Technol. 3:50-64.

Babatunde, F.E. (2001). Response of red varient roselle (Hibiscus sabdariffa $\mathrm{L}$.) to some agronomic practices. Ph.D. Thesis, Abubakar Tafawa Balewa University, Bauchi. Pp.108. (Unpublished)

Dike, M.C. (1987). Insect pests of kenaf and roselle in the Zaria area of northern Nigeria. A paper presented at the $17^{\text {th }}$ Annual Conference of the Nigerian Society for Plant Protection. University of Nigeria, Nsukka.

El-Gamel, E.S.A., Mohamoud, M.M. and Oman, F.A. (1983). Effect of nitrogen fertilization on the growth and yield of Hibiscus sabdariffa L. Ann. Agric. Sci. 28(2): 839-850.

Gibbon, D. and Adam, P. (1985). Crops of Drier Regions of the Tropics. Longman Groups Limited, London, pp. 61-62.

Kumar, V. Idem, N.U.A. and Echekwu, C.A. (1986). Yield components of roselle varieties in Northern Nigeria. East Afr. J. Agric. 51: 108-112.

Mahran, G.H., El-Hossary, G.A. and El-Laban, H.M. (1978). The effect of nutrient elements on the growth and yield of Hibiscus sabdariffa Planta Medica 33: 293-294.
MSU, (Michigan State University) (1985). Microcomputer programme for design, management and analysis of agronomic research experiments.

MSU, Michigan.Mugwira, L.M. (1985). Effects of supplementing communal area manure with lime and fertilizer on plant growth and nutrient uptake. Zim. Agric. J. 82: 153-159.

Okosun, L.A. (2000). Effect of plant density, sowing date and fertilizer on the growth and yield of roselle (Hibiscus sabdariffa L.) in the Sudan savanna. Ph.D thesis. Usmanu Danfodiyo University, Sokoto, pp.186. (Unpublished)

Panchoo, L. and Rhoden, E.G. (1990). Effect of transplant timing and terminal bud removal on sorrel. Caribbean Food Crop Soc. Proceeding. 26: 245-254.

Paschadilis, C.D. Stavrinos, E.A., Mitsios, J.K., and Cristidou, S.V. (1997). Effect of nitrogen uptake and utilization on the growth and the yield characteristics of kenaf in entisols. Field crops Abstract 51(4): 372.

Purseglove, J.W. (1969). Tropical Crops Dicotyledons Vol. 1 and 2 combined. Longman Group Limited England. First pub. 1968- pp 370-372.

Sarker, S.K., Ghosh, R.K. Sounda, G. Maitra, S. Roy, D.K. and Ghosh, K. (1997). Effect of levels of nitrogen, potassium and soil moisture tension on growth nutrient uptake and water use efficiency of jute. Field Crop Abstract 51(7):696.

Selim, S.M.A., Rokba, A.M. Hassan, M.R. and Hussain, M.A. (1993). Effect of sowing dates, nitrogenous and potassium fertilization on roselle plant. Egypt. J. Hort 20: 87-96.

Tindall, H.D. (1983). Vegetables in the Tropics English language book society. Macmillan Company. London. Pp 32-41.

Tindall, H. D. (1992). Vegetables in the Tropics. Macmillan Press Ltd., London, p 533. 